\title{
PENGARUH TEMPERATUR CETAKAN DAN LAMA PENGEMPAAN TERHADAP KETEGUHAN REKAT PADA KAYU LAPIS SEBAGAI BAHAN BAKU PEMBUATAN DRUM SHELL
}

\author{
Eko Budiyanto, Asroni, Atik Pramono \\ Jurusan Teknik Mesin, Fakultas Teknik, Universitas Muhammadiyah Metro \\ Jl. Ki Hajar Dewantara 15 A Metro, Lampung \\ Email: eko_budiyanto99@yahoo.com, asroni@engineer.com, atikpramono123@yahoo.com
}

\begin{abstract}
Abstrak
Drum shell (selongsong drum) secara garis besar terdiri dari 2 jenis, yaitu ply by ply shell dan solid shell. Penelitian ini ditujukan untuk proses pembuatan drum shell jenis ply by ply shell. Yang dimaksud dengan ply by ply adalah shell-nya terbuat dari kayu yang berlapislapis, seperti teak block atau triplek. Semakin banyak lapisannya maka suara yang dihasilkan semakin tinggi. Penelitian ini bertujuan untuk mengetahui pengaruh temperatur cetakan dan lama pengempaan terhadap keteguhan rekat kayu lapis dan prosentase kerusakan kayu. Variabel bebas yang digunakan dalam penelitian ini adalah 3 variasi temperatur $\left(85^{\circ} \mathrm{C}, 90^{\circ} \mathrm{C}\right.$, $95^{\circ} \mathrm{C}$ ) dan 3 variasi lama pengempaan ( 2 jam, 3 jam dan 4 jam). Pengambilan data dilakukan dalam dua tahap yaitu data keteguhan rekat (KR) yang diperoleh dengan menggunakan metode pengujian kekuatan geser rekat yang dilakukan menurut standar ASTM D-905-49 tahun 1981 serta data prosentase kerusakan kayu (KK) yang dihitung menggunakan software Autocad 2007. Selanjutnya data dianalisa dan dibuat grafik yang akan digunakan untuk mengetahui pengaruh temperatur cetakan dan lama pengempaan terhadap keteguhan rekat dan prosentase kerusakan kayu. Hasil penelitian menunjukkan bahwa peningkatan temperatur cetakan dan lama pengempaan berbanding lurus dengan keteguhan rekat dan prosentase kerusakan kayu dan temperatur cetakan tidak berpengaruh terhadap kapasitas produksi sedangkan lama pengempaan berbanding terbalik dengan kapasitas produksi drum shell per hari. Dalam penelitian ini, nilai keteguhan rekat terbesar terjadi pada temperatur cetakan $90^{\circ} \mathrm{C}$ dan lama pengempaan 4 jam dengan nilai keteguhan rekat sebesar $23,25 \mathrm{~kg} / \mathrm{cm}^{2}$. Dan nilai keteguhan rekat terkecil terjadi pada temperatur cetakan $85^{\circ} \mathrm{C}$ dan lama pengempaan 2 jam dengan nilai keteguhan rekat sebesar $19,25 \mathrm{~kg} / \mathrm{cm}^{2}$.
\end{abstract}

Kata kunci : Temperatur, Lama Pengempaan, Keteguhan Rekat, Kayu Lapis, Drum Shell.

\section{PENDAHULUAN}

Perkembangan industri di Indonesia sekarang ini berlangsung sangat pesat seiring kemajuan ilmu pengetahuan dan teknologi. Proses industrialisasi masyarakat Indonesia makin cepat dengan berdirinya perusahaan dan tempat kerja yang beraneka ragam. Perkembangan yang dialami tidak hanya peningkatan, tetapi juga penurunan. Sehingga dari tahun ke tahun perindustrian di Indonesia mengalami fluktuasi. Mulai dari sektor pertanian, kerajinan tangan, makanan, properti dan lain sebagainya setiap tahun mengalami peningkatan dan penurunan. Seperti industri alat musik di Indonesia. Perkembangan industri alat musik di dalam negeri sebenarnya cukup potensial. Menurut Kementrian Perindustrian, ada beberapa produsen alat musik di Indonesia dengan nilai investasi yang sangat besar dan menyerap tenaga kerja yang sangat banyak.

Salah satu industri alat musik di Indonesia adalah industri drum, karena alat musik drum telah menjadi alat musik yang sangat diminati oleh berbagai kalangan masyarakat. Seiring dengan meningkatnya 
peminat alat musik jenis drum ini, drum dengan material kayu adalah yang paling banyak diminati karena drum yang terbuat dari kayu menjanjikan suara yang lebih lembut dan baik menurut selera pemakai. Namun seiring dengan semakin langkanya material kayu utuh, maka material dari kayu lapis selanjutnya menjadi pilihan yang baik. Selain lebih mudah didapat, juga mewakili sifat-sifat dari kayu.

Menurut Departemen Kehutanan, dalam tulisannya tentang sifat-sifat kayu dan penggunaannya, bahwa kayu memiliki sifat-sifat terhadap suara, antara lain: Pertama, sifat Akustik, yaitu kemampuan material kayu untuk meneruskan suara yang berkaitan erat dengan elastisitas kayu. Kedua, sifat resonansi, yaitu turut bergetarnya kayu akibat adanya gelombang suara. Kualitas nada yang dikeluarkan kayu sangat baik, sehingga kayu banyak dipakai untuk bahan pembuatan alat music [1] .

Hal tersebut mendorong penulis mengadakan penelitian mengenai pembuatan drum shell jenis ply by ply shell berbahan baku kayu lapis jenis jati. Namum dalam proses pembuatannya, penulis dihadapkan pada pengempaan dingin yang memakan waktu terlampau lama sehingga tidak memungkinkan untuk dikerjakan untuk produksi masal. Oleh karena itu penulis mengadakan penelitian dengan memberikan perlakuan panas dalam proses perekatan antar lapisan drum shell. Perlakuan panas ini bertujuan untuk mempercepat proses pengerasan perekat. Namun, dalam hal ini perlu diadakan penelitian mengenai seberapa besar keteguhan rekat dari proses perekatan tersebut.

\section{KAJIAN LITERATUR}

\section{Drum shell}

Drum shell adalah selongsong dari sebuah drum. Drum shell ada yang terbuat dari kayu ada juga yang terbuat dari logam. Ada juga yang terbuat dari bambu. Perbedaan material drum shell akan besar sekali perbedaan suara yang dihasilkan.
Drum shell yang terbuat dari kayu menghasilkan suara yang hangat. Lebih lembut dibandingkan dengan yang terbuat dari logam, tapi bukan berarti drum shell yang terbuat dari kayu selalu lebih baik dari pada yang terbuat dari logam, karena ini masalah selera dan kebutuhan [2].

Kayu yang digunakan untuk membuat drum shell ada banyak macamnya, seperti kayu Maple, Birch, Ebony, Oak, Jati, Mahoni atau kayu-kayu lainnya. Masing-masing jenis kayu menghasilkan suara yang berbeda-beda [2].

\section{a. Ply by ply shell}

Yang dimaksud dengan ply by ply adalah shell-nya terbuat dari kayu yang berlapis-lapis, seperti teak block atau triplek. Semakin banyak lapisannya maka suara yang dihasilkan semakin tinggi [2]. Kelebihan dari ply by ply antara lain :

$\checkmark$ Ekonomis

$\checkmark$ Bahannya relativ mudah didapatkan

$\checkmark$ Lebih mudah dalam pembentukan selongsong atau shell-nya

$\checkmark$ Untuk membuat selongsong atau drum shell yang tipis lebih mudah

$\checkmark$ Fleksibel

$\checkmark$ Daya tahan cukup kuat

$\checkmark$ Cocok sekali untuk pembuatan masal

Sementara kekurangannya antara lain :

$\checkmark$ Pilihan kayunya terbatas

$\checkmark$ Banyak menggunakan lem yang mana banyak yang percaya bahwa penggunaan lem itu akan mempengaruhi suara yang dihasilkan.

$\checkmark \quad$ Lebih mudah mengalami deformasi.

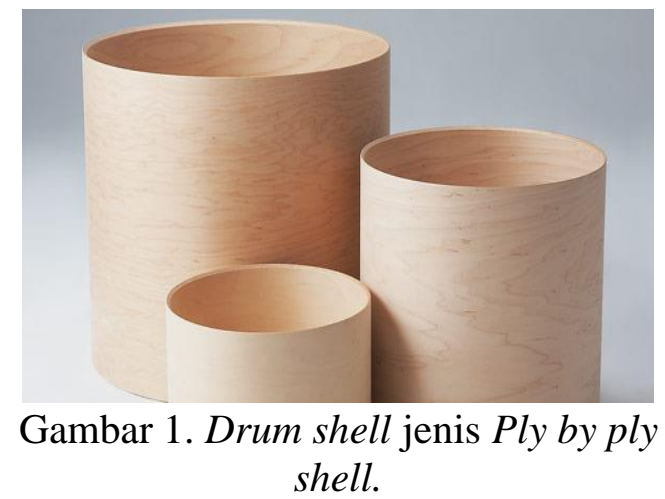




\section{b.Solid Shell}

Sesuai dengan namanya, drum shell ini terbuat dari kayu utuh. Jadi satu kayu gelondongan begitu kemudian dibuat menjadi satu drum shell tanpa sambungan. Karakter drum yang menggunakan solid shell ini diyakini menghasilkan suara yang lebih baik. Kebanyakan drum yang menggunakan solid shell ini adalah jenis snare drum karena ukurannya yang tidak terlalu besar, mengingat sekarang sangat sulit memperoleh kayu gelondongan dengan ukuran besar [2]. Kelebihan solid shell:

$\checkmark$ Karena kayunya asli kayu gelondongan yang dibobok dan dijadikan drum shell, maka tidak ada lem yang digunakan sehingga kualitas suara yang dihasilkan sempurna.

$\checkmark \quad$ Tidak membutuhkan lem sama sekali.

$\checkmark$ Bentuknya unik dan termasuk produk langka.

Kekurangan :

$\checkmark$ Material kayunya sulit didapatkan.

$\checkmark$ Membutuhkan peralatan yang lebih dibanding membuat ply by ply shell

$\checkmark \quad$ Teknik pembuatannya yang juga sulit karena hanya sedikit yang membuatnya sehingga informasi mengenai teknik pembuatan solid shell ini tidak tersedia secara luas.

$\checkmark$ Sangat sulit untuk membuat shell atau selongsong yang tipis.

$\checkmark \quad$ Hanya cocok untuk shell yang tebal

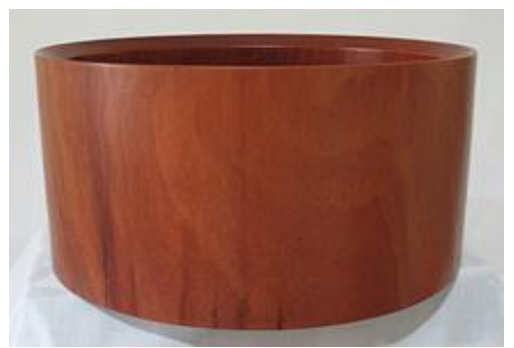

Gambar 2. Drum shell jenis solid shell

Secara garis besar semakin tebal tabung drum shell maka semakin tinggi frekuensi suara yang dihasilkan dan semakin tipis maka semakin rendah frekuensi suara yang dihasilkan [3].

Beberapa produsen drum mempunyai standar ketebalan lapisan yang berbedabeda. Kepadatan kayu berhubungan dengan berat jenis lapisan kayu per lembar. Sebagai contoh luan wood (sejenis kayu keras yang hampir mirip dengan mahoni) akan lebih tebal lapisannya dibandingkan dengan kayu Birch. Karena kayu Birch lebih keras, kuat dan dapat dipotong lebih tipis. Atau sebuah perusahaan produsen drum shell membuat 9 lapisan kayu namun lebih tipis dibandingkan dengan produsen lainnya yang memproduksi 6 lapisan drum shell. Membuat drum shell dari banyak lapisan dan bukan dari satu kayu tebal yang utuh adalah menembah kekuatan dan stabilitas pada shell [3].

Jumlah lapisan berpengaruh seberapa besar energi yang dikirim dari head drum ke tabung/shell. Ini adalah suatu factor yang mempunyai efek yang mendalam dari karakter warna suara (tonal) dan proyeksi drum.

Dibawah ini adalah diagram yang diambil dari hasil riset Gene Okamoto Pearl Drums.

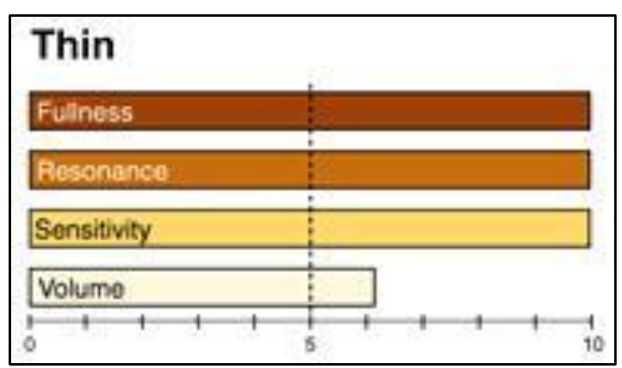

Gambar 3. Diagram drum shell tipis [3]

Shell yang tipis /thin (4 ply/5 mm) lebih mudah mengirim energi resonansi dari head / membran ke tabung yang sangat kaya dengan karakter warna suara kayu serta bisa sangat berharga dalam aplikasi suara yang dekat dengan obyek khususnya dalam rekaman. 


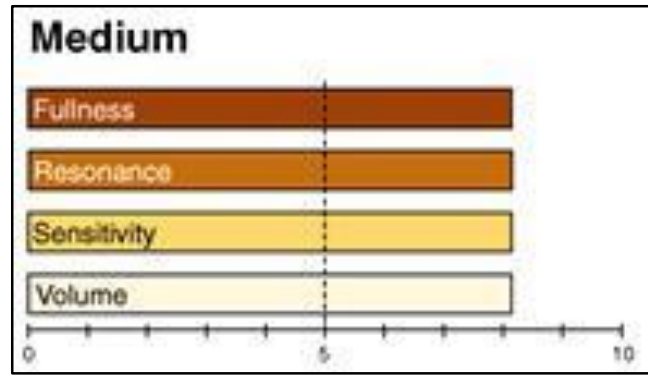

Gambar 4. Diagram drum shell medium [3].

Shell yang memiliki ketebalan medium (6 ply/7,5 mm) lebih keras dan menahan energi yang dikirim dari membran. Dengan getaran yang kurang dan suara sedikit lebih lembut dibandingkan dengan shell yang tipis, namun suara yang dihasilkan terasa lebih menonjol. Drum shell dengan ketebalan seperti ini adalah ideal untuk segala jenis tujuan atau keperluan.

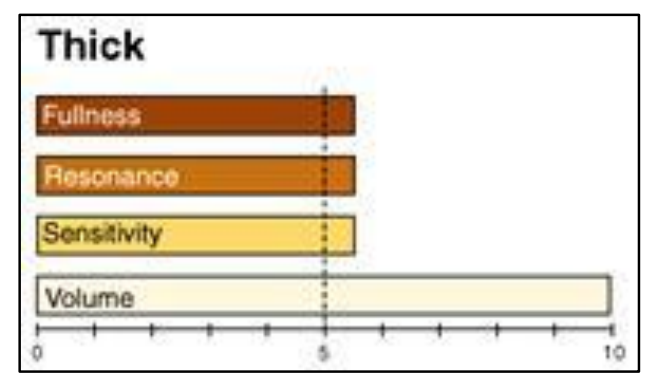

Gambar 5. Diagram drum shell tebal [3].

Shell yang tebal (thick / 8 ply $10 \mathrm{~mm}$ dan 10 ply $12,5 \mathrm{~mm}$ ) adalah benar-benar efisien dan memberikan energi kepada seluruh pemain drum untuk fokus kepada audiens. Dan tipe ini ideal digunakan untuk acara music di tempat yang besar seperti stadion dan lain-lain dan untuk aplikasi yang membutuhkan high sound. Snare drum tipe ini bersaing dengan snare drum berbahan metal dalam hal kepadatan dan proyeksi suara drum.

\section{Kayu}

Dalam kehidupan kita sehari-hari, kayu merupakan bahan yang sangat sering dipergunakan untuk tujuan penggunaan tertentu. Terkadang sebagai barang tertentu, kayu tidak dapat digantikan dengan bahan lain karena sifat khasnya. Kita sebagai pengguna dari kayu yang setiap jenisnya mempunyai sifat-sifat yang berbeda, perlu mengenal sifat-sifat kayu tersebut sehingga dalam pemilihan atau penentuan jenis untuk tujuan penggunaan tertentu harus betul-betul sesuai dengan yang kita inginkan.

\section{a. Sifat Fisik Kayu}

1) Berat dan Berat Jenis (BJ)

Berat suatu kayu tergantung dari jumlah zat kayu, rongga sel, kadar air dan zat ekstraktif didalamnya. Berat suatu jenis kayu berbanding lurus dengan BJnya. Kayu mempunyai berat jenis yang berbeda-beda, berkisar antara BJ minimum 0,2 (kayu balsa) sampai BJ 1,28 (kayu nani). Umumnya makin tinggi BJ kayu, kayu semakin berat dan semakin kuat pula.

2) Keawetan

Keawetan adalah ketahanan kayu terhadap serangan dari unsur-unsur perusak kayu dari luar seperti jamur, rayap, bubuk dll. Keawetan kayu tersebut disebabkan adanya zat ekstraktif didalam kayu yang merupakan unsur racun bagi perusak kayu. Zat ekstraktif tersebut terbentuk pada saat kayu gubal berubah menjadi kayu teras sehingga pada umumnya kayu teras lebih awet dari kayu gubal.

3) Warna

Kayu yang beraneka warna macamnya disebabkan oleh zat pengisi warna dalam kayu yang berbeda-beda.

4) Tekstur

Tekstur adalah ukuran relatif sel-sel kayu. Berdasarkan teksturnya, kayu digolongkan kedalam kayu bertekstur halus (contoh: giam, kulim dll), kayu bertekstur sedang (contoh: jati, sonokeling dll) dan kayu bertekstur kasar (contoh: kempas, meranti dll).

5) Arah Serat

Arah serat adalah arah umum sel-sel kayu terhadap sumbu batang pohon. Arah serat dapat dibedakan menjadi serat lurus, serat berpadu, serat berombak, serta terpilin dan serat diagonal (serat miring). 
6) Kesan Raba

Kesan raba adalah kesan yang diperoleh pada saat meraba permukaan kayu (kasar, halus, licin, dingin, berminyak dll). Kesan raba tiap jenis kayu berbedabeda tergantung dari tekstur kayu, kadar air, kadar zat ekstraktif dalam kayu.

7) Bau dan Rasa

Bau dan rasa kayu mudah hilang bila kayu lama tersimpan di udara terbuka. Beberapa jenis kayu mempunyai bau yang merangsang dan untuk menyatakan bau kayu tersebut, sering digunakan bau sesuatu benda yang umum dikenal misalnya bau bawang (kulim), bau zat penyamak (jati), bau kamper (kapur) dsb.

8) Nilai Dekoratif

Gambar kayu tergantung dari pola penyebaran warna, arah serat, tekstur, dan pemunculan riap-riap tumbuh dalam pola-pola tertentu. Pola gambar ini yang membuat sesuatu jenis kayu mempunyai nilai dekoratif.

9) Higroskopis

Kayu mempunyai sifat dapat menyerap atau melepaskan air. Makin lembab udara disekitarnya makin tinggi pula kelembaban kayu sampai tercapai keseimbangan dengan lingkungannya. Dalam kondisi kelembaban kayu sama dengan kelembaban udara disekelilingnya disebut kandungan air keseimbangan $(\mathrm{EMC}=$ Equilibrium Moisture Content $)$.

10) Sifat Kayu terhadap Suara, yang terdiri dari :

Sifat akustik, yaitu kemampuan untuk meneruskan suara berkaitan erat dengan elastisitas kayu.

Sifat resonansi, yaitu turut bergetarnya kayu akibat adanya gelombang suara. Kualitas nada yang dikeluarkan kayu sangat baik, sehingga kayu banyak dipakai untuk bahan pembuatan alat musik (kulintang, gitar, biola dll).
11) Daya Hantar Panas

Sifat daya hantar kayu sangat jelek sehingga kayu banyak digunakan untuk membuat barang-barang yang berhubungan langsung dengan sumber panas.

12) Daya Hantar Listrik

Pada umumnya kayu merupakan bahan hantar yang jelek untuk aliran listrik. Daya hantar listrik ini dipengaruhi oleh kadar air kayu. Pada kadar air $0 \%$, kayu akan menjadi bahan sekat listrik yang baik sekali, sebaliknya apabila kayu mengandung air maksimum (kayu basah), maka daya hantarnya boleh dikatakan sama dengan daya hantar air [4].

\section{b. Sifat Mekanik Kayu}

Sifat mekanikal material kayu bisa dilihat dan dianalisa berdasarkan uraian berikut [4]:

1) Kekuatan Tarik

Dua arah kekuatan tarik pada kayu yaitu searah serat kayu atau tegak lurus (melintang) arah serat kayu. Kekuatan tarik kayu adalah bagaimana reaksi bahan kayu terhadap gaya-gaya yang menarik kayu. Pada umumnya kayu memiliki kekuatan tarik lebih besar searah serat kayu.

2) Kekuatan Tekan

Adalah daya tahan kayu terhadap tekanan pada searah serat kayu atau melintang serat kayu. Kekuatan tekan kayu lebih lemah pada arah melintang serat.

3) Keteguhan Geser

Keteguhan geser adalah kekuatan kayu menahan gerakan dan tekanan yang membuat kayu bergeser (tanpa pukulan) baik itu beban mati ataupun beban hidup. Beban mati artinya tekanan secara terus menerus pada skala tekanan tertentu. Sedangkan beban hidup berarti tekanan yang berulang-ulang dan bisa berubah-ubah kekuatannya. Keteguhan 
geser kayu paling besar adalah pada posisi melintang serat kayu.

4) Kelenturan (Kekuatan Lengkung) Kayu juga tahan terhadap gaya yang berusaha melengkungkan kayu dengan satu kali tekanan secara terus menerus atau berkali-kali (secara mendadak, seperti pukulan).

5) Kekuatan Belah

Daya tahan kekuatan kayu terhadap tekanan belah paling rendah pada posisi searah serat. Walaupun demikian untuk beberapa jenis kayu tertentu sangat baik apabila kekuatan belahnya sangat lemah karena jenis kayu ini akan sangat cocok untuk pembuatan atap sirap.

\section{Keteguhan Perekatan}

Perekatan kayu adalah usaha menggabungkan dua permukaan kayu dengan perantara menggunakan bahan perekat. Perekatan diartikan sebagai suatu keadaan di mana dua permukaan bahan menjadi satu oleh karena adanya gaya-gaya pengikat antar permukaan benda tersebut. Gaya-gaya ini dapat berupa gaya valensi (ikatan ion) dan gaya saling mencengkeram (interlocking forces) antara perekat dengan bahan direkat [5].

Dalam pembentukan ikatan perekatan, untuk menghasilkan ikatan yang kuat perekat harus melalui beberapa tahap secara sempurna, yaitu [5] :

1. Flow (pengaliran), yaitu ketika perekat mengalir ke seluruh permukaan kayu yang direkat secara merata dan membentuk lapisan film yang kontinu.

2. Transfer (pemindahan), yaitu berpindahnya perekat dari bagian yang terlabur ke bagian yang tidak terlaburi perekat.

3. Penetration (penetrasi), yaitu penembusan perekat ke dalam kayu yang akan direkat.

4. Wetting (pembasahan), pembasahan kayu oleh pelarut perekat.
5. Solidification (pengerasan), yaitu pengerasan perekat menjadi wujud yang solid dan kuat.

Kemampuan perekat untuk melewati tahap-tahap tersebut secara sempurna sangat bergantung pada mobilitas (sifat alir) bahan perekat, tipe perekat dan kondisi permukaan kayu [5].

Selanjutnya perekatan dapat dianalisa sebagai satu system yang terdiri dari lima buah gaya yang berbeda satu sama lain yang berasosiasi bersama membentuk suatu garis perekat. Teori ini dikenal dengan istilah Five Chains Glue Line. Dalam teori ini pada prinsipnya kekuatan perekatan ditentukan oleh 3 gaya ikatan antara lain [5]:

1. Gaya kohesi antar molekul kayu dalam mempertahankan keutuhan bentuk fisiknya.

2. Gaya adhesi antara molekul kayu dengan molekul perekat dalam mempertahankan keutuhan ikatan antara kedua bahan.

3. Gaya kohesi antar molekul perekat dalam mempertahankan keutuhan garis perekatnya.

Pada teori yang kedua, system perekatan dibagi ke dalam dua komponen gaya perekaan yang saling berinteraksi yaitu perekatan spesifik dan perekatan mekanik. Perekatan spesifik merupakan gaya perekatan yang kekuatannya ditentukan oleh sifat perekatnya sendiri (inherent characteristics) dan kompabilitas atau kemampuan penyesuaian antara bahan yang direkat dengan bahan perekatnya. Perekatan mekanik adalah gaya perekatan yang dibentuk oleh masuknya bahan perekat ke dalam substrat/bahan direkat yang mengeras membentuk akar-akar garis perekat yang disebut interlocking forces. Kekuatan gaya ditentukan oleh terbentuknya akar-akar garis perekat yang dianalogikan sebagai kekuatan cengkeraman sehingga kedua komponen gaya ini secara bersama-sama berkontribusi terhadap total kekuatan perekatan [5].

Teori perekatan yang kedua ini tidak selalu berlaku untuk semua bahan. Pada 
bahan yang sifat permukaannya tidak porus atau tidak diresapi perekat seperti kaca misalnya maka tidak akan terbentuk akar garis perekat yang merupakan unsure kekuatan perekatan mekanik, sehingga yang berkontribusi terhadap kekuatan perekatan hanya perekatan spesifik [5].

Keberhasilan suatu perekatan sangat ditentukan oleh perhitungan yang matang dan teliti terhadap kesiapan dan kondisi bahan perekat maupun bahan direkat. Dalam hal ini kayu merupakan factor bahan direkat yang harus mendapat perhatian. Beberapa parameter yang harus diperhatikan sehubungan dengan penggunaan kayu sebagai bahan bahan direkat antara lain adalah : kerapatan, berat jenis, porositas, kapilaritas, wettabilitas, kekasaran permukaan dan kadar air.

Secara umum faktor-faktor yang berpengaruh terhadap kualitas produk perekatan kayu dapat dikelompokkan menjadi tiga kelompok besar. Kelompok pertama adalah bahan direkat (adherent) kayu, seperti struktur anatomi kayu, sifat fisika kayu dan sifat kimia kayu. Bahan perekat (adhesive) merupakan kelompok factor yang kedua, dimana sifat bahan perekat beserta bahan-bahan tambahan, yaitu pengisi (filler), pengembang (extender), pengeras (hardener) atau bahan tambahan lain dengan tujuan khusus, seperti bahan penangkap, bahan pengawet dan bahan tahan api, akan mempengaruhi kualitas perekatan yang dihasilkan. Kelompok terakhir adalah teknologi dan proses perekatan yang digunakan, seperti cara pelaburan perekat dan system pengempaan [5].

\section{Pengempaan Kayu Lapis}

Pengempaan dikelompokkan menjadi 2 (dua) yaitu hot press (kempa panas) dan cold press (kempa dingin). Sebagian besar kayu lapis diproduksi dengan menggunakan kempa panas. Besarnya berkisar antara 100-250 psi tergantung kerapatan kayunya. Untuk jenis kayu dengan kerapatan rendah berkisar 100-150 psi, untuk jenis kayu dengan kerapatan sedang berkisar 150-200 psi serta untuk kayu dengan kerapatan tinggi berkisar 200250 psi. Besarnya temperatur pengempaan tergantung pada jenis perekat yang digunakan. Kempa dingin dilakukan apabila perekat yang dipakai adalah perekat alami atau perekat sintetik yang mengeras pada suhu ruang. Besarnya tekanan pada pengempaan dingin berkisar antara 150 350 psi tergantung pada kerapatan kayu. Penggunaan pengempaan dingin sulit untuk mendapatkan keseragaman ketebalan pada kayu lapis yang dibuat [6].

\section{Temperatur dan waktu pengempaan}

Dalam proses pengempaan terdapat interaksi yang terjadi antara temperatur dan waktu pengempaan. Berikut ini adalah pengaruh suhu dan waktu pengempaan terhadap sifat fisik dan mekanik papan partikel kayu sengon [7] :

\section{Pengaruhnya terhadap berat kadar air}

Faktor suhu dan waktu pengempaan mempunyai pengaruh yang sangat nyata pada jenjang nyata $99 \%$. Nilai kadar air yang diperoleh dengan variasi suhu pengempaan yang digunakan yaitu $100^{\circ} \mathrm{C}$, $130^{\circ} \mathrm{C}$ dan $160^{\circ} \mathrm{C}$ berturut-turut adalah $11,46 \%, 9,37 \%$ dan $7,77 \%$. Sedangkan nilai rata-rata kadar air berdasarkan faktor waktu pengempaan yaitu 5 menit, 7,5 menit dan 10 menit berturut-turut adalah $10,02 \%$, $9,6 \%$ dan $8,97 \%$.

\section{Pengaruhnya terhadap berat jenis}

Hasil penelitian yang telah dilakukan menyatakan bahwa faktor suhu dan waktu pengempaan mempunyai pengaruh yang sangat nyata pada peluang $99 \%$. Nilai ratarata berat jenis papan partikel yang diperoleh dari variasi suhu pengempaan yang digunakan yaitu $100^{\circ} \mathrm{C}, 130^{\circ} \mathrm{C}$ dan $160^{\circ} \mathrm{C}$ berturut-turut adalah $0,48 \% \mathrm{~kg} / \mathrm{cm}^{2}$, $0,63 \mathrm{~kg} / \mathrm{cm}^{2}$ dan $0,69 \mathrm{~kg} / \mathrm{cm}^{2}$. Hal ini menunjukkan bahwa semakin meningkat suhu pengempaan menyebabkan bertambahnya berat jenis partikel. Bertambahnya berat jenis papan partikel ini dimungkinkan karena suhu tinggi 
mendukung proses perekatan yang lebih baik. Sedangkan nilai rata-rata berat jenis yang diperoleh dari variasi waktu pengempaan yang digunakan yaitu 5 menit, 7,5 menit dan 10 menit berturut-turut adalah $0,56 \mathrm{~kg} / \mathrm{cm}^{2}, 0,62 \mathrm{~kg} / \mathrm{cm}^{2}$ dan 0,65 $\mathrm{kg} / \mathrm{cm}^{2}$. Bertambahnya berat jenis ini dimungkinkan karena waktu pengempaan yang lama. Hal ini karena semakin lama waktu pengempaan maka proses perekatan akan semakin sempurna.

\section{Pengaruhnya terhadap penyerapan air}

Berdasarkan hasil penelitian yang telah dilakukan menunjukkan bahwa faktor suhu tidak berpengaruh nyata. Sedangkan faktor waktu pengempaan mempunyai pengaruh yang nyata.

\section{Pengembangan tebal}

Faktor suhu pengempaan mempunyai pengaruh yang sangat nyata terhadap pengembangan tebal. Sedangkan faktor waktu pengempaan tidak menunjukkan pengaruh yang nyata.

5. Keteguhan tekan sejajar permukaan

Faktor suhu pengempaan dalam pembuatan papan partikel kayu sengon mempunyai penngaruh yang sangat nyata pada keteguhan tekan sejajar permukaan. Namun faktor waktu pengempaan tidak mempunyai pengaruh yang nyata.

\section{Keteguhan lengkung static}

Nilai modulus elastisitas (MOE) dan nilai modulus patah diperoleh dengan pengujian keteguhn lengkung static. Modulus elastisitas ini menunjukkan kemampuan suatu benda untuk menahan bean dari arah tegak lurus mengenai benda tersebut yang berusaha yang berusaha untuk mematahkannya. Dikatakan bahwa waktu kempa mempunyai pengaruh yang nyata terhadap nilai MOE papan partikel dan hasilnya cenderung meningkat apabila faktor suhu dan waktu kempanya dinaikkan.

\section{Perlakuan panas pada kayu}

Proses perlakuan panas (heat treatment) pada kayu merupakan suatu proses di mana kayu mendapat perlakuan panas dengan uap atau dalam air pada suhu tinggi. Apabila tidak terdapat unsur air dalam perlakuannya maka disebut proses thermal, sedangkan apabila terdapat unsur air atau uap di dalam perlakuannya maka disebut proses hydro-thermal. Proses ini ditujukan utuk memperbaiki sifat-sifat kayu. Pemanasan dilakukan dalam suatu instalasi pemanas dari teknologi sederhana sampai pada berteknologi tinggi. Kayu dipanaskan pada suhu antara 180 - 250 derajat celcius untuk durasi tertentu [5].

Modifikasi kayu melalui perlakuan pemanasan merupakan metode yang efektif dalam rangka memperbaiki stabilitas dan daya tahan terhadap kerusakan yang disebabkan oleh jamur pembusuk. Perlakuan ini biasanya dilakukan pada jenis kayu yang tingkat keawetannya rendah. Modifikasi panas pada suhu tinggi (diatas $170^{\circ} \mathrm{C}$ ) dapat merubah sifat kimia dari komponen penyusun kayu (poliosa, selulosa dan lignin). Proses perlakuan panas memerlukan kondisi khusus seperti waktu dan temperatur serta tergantung pada jenis kayu [6].

Ikatan kimia kayu hasil dari percobaan perlakuan panas dapat memperbaiki sifat kayu terutama menurunkan sifat higroskopik dan memperbaiki stabilitas dimensi, sementara penyerapan minyak oleh kayu dapat menurunkan penyerapan air.

Terdapat 3 (tiga) teori yang berbeda untuk menjelaskan perbaikan daya tahan terhadap jamur sebagai akibat dari perlakuan panas, antara lain [6] :

1. Mengurangi pentose sebagai sumber nutrisi utama sehingga penyebaran jamur tahap awal dapat dihentikan.

2. Perbaikan daya tahan terhadap jamur melalui modifikasi sifat kayu. Retikulasi molekul (misalnya furfural yang dibentuk melalui dekomposisi panas) pada jaringan lignin dapat mengakibatkan system enzimatik 
jamur tidak dapat mengenali substrat (kayu).

3. Menjadikan racun sebagai akibat adanya formasi molekul bebas. Misalnya ekstraksi Pinus pinaster $L$ melalui modifikasi termal telah menghasilkan racun polinuklir turunan hidrokarbon aromatik semacam senyawa poliaromatik.

\section{METODE PENELITIAN}

Penelitian dilakukan di Workshop Universitas Muhammadiyah Metro yang dilaksanakan sejak bulan Maret 2016 hingga bulan April 2016. Peralatan yang digunakan dalam penelitian ini antara lain sebagai berikut:

1) Oven

2) Tanggem (Vice)

3) Alat pres manual dengan alat ukur analog

4) Pressure Gage

5) Thermometer

6) Kamera digital

7) Vernier Caliper

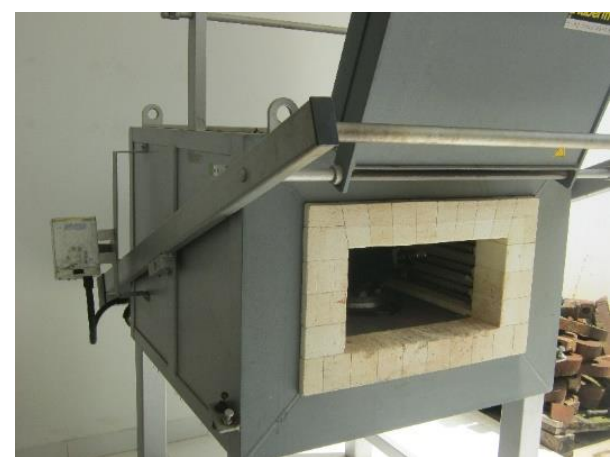

Gambar 6. Oven merk Nabertherm.

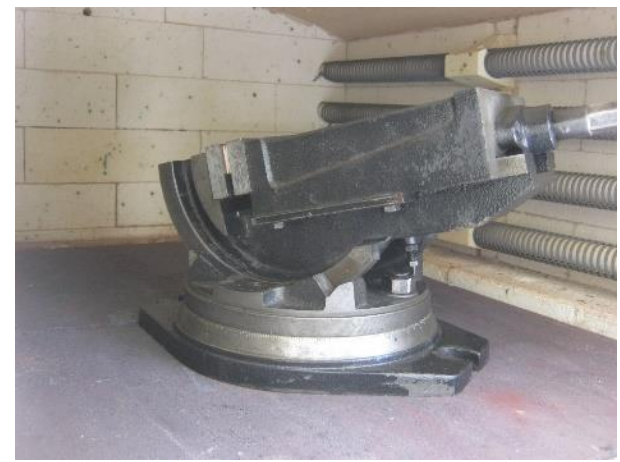

Gambar 7. Tanggem (vice).

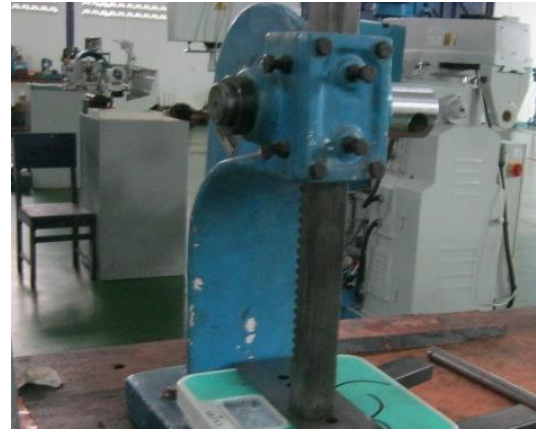

Gambar 8. Alat pres.

Bahan yang digunakan dalam penelitian ini adalah Kayu lapis jati tebal 3,0 mm dan Lem putih PVAc merek Fox.

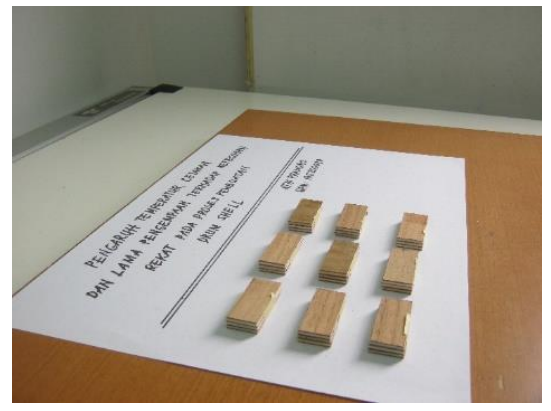

Gambar 9. Kayu lapis jati.

\section{Proses pengempaan}

1. Persiapan sampel

a. Pemotongan material kayu lapis jati sesuai ukuran yang dibutuhkan, yaitu panjang $20 \mathrm{~mm}$ x lebar $50 \mathrm{~mm}$ sebanyak 27 buah.

b. Semua benda uji yang telah disiapkan kemudian dibersihkan dari semua kotoran dan debu.

c. Semua benda uji direbus selama 5 menit dengan suhu 80 derajat celcius dengan tujuan untuk menyamakan proses dengan pembuatan drum shell lalu dikeringkan kembali seperti keadaan semula dengan suhu 95 derajat celcius selama 2 jam kemudian dibiarkan dalam suhu kamar selama paling sedikit 2 jam.

2. Proses pengempaan

a. Proses perekatan benda uji dilakukan 3 layer kayu lapis dengan melumuri masing-masing permukaan yang akan direkatkan 
dengan perekat lem putih PVAc merek Fox.

b. Proses selanjutnya dilakukan pengempaan pada masing-masing 3 layer lapisan tersebut dengan menggunakan alat pengempa yang dimasukkan ke dalam mesin pemanas otomatis sesuai dengan tabel pengempaan.

Tabel 1. Tabel proses pengempaan sampel

\begin{tabular}{|c|c|c|c|}
\hline No & $\begin{array}{c}\text { Kode } \\
\text { Sampel }\end{array}$ & $\begin{array}{c}\text { Lama } \\
\text { Pengempaan } \\
\text { (jam) }\end{array}$ & $\begin{array}{c}\text { Temperatur } \\
\text { Cetakan } \\
\left({ }^{\circ} \mathrm{C}\right)\end{array}$ \\
\hline 1 & S2-85 & 2 & 85 \\
\hline 2 & S2-90 & 2 & 90 \\
\hline 3 & S2-95 & 2 & 95 \\
\hline 4 & S3-85 & 3 & 85 \\
\hline 5 & S3-90 & 3 & 90 \\
\hline 6 & S3-95 & 3 & 95 \\
\hline 7 & S4-85 & 4 & 85 \\
\hline 8 & S4-90 & 4 & 90 \\
\hline 9 & S4-95 & 4 & 95 \\
\hline
\end{tabular}

3. Setelah selesai masing-masing benda uji dibiarkan dalam suhu kamar selama setidaknya 24 jam untuk dilakukan pengujian kekuatan rekat.

\section{Pengujian kekuatan rekat}

Pengujian kekuatan geser rekat dilakukan menurut standar sesuai standar ASTM D-905-49 tahun 1981 dengan ukuran nominal $20 \mathrm{~mm}$ x $50 \mathrm{~mm}$ yang dibuat dengan memotong kayu lapis. Pengujian dilakukan pada kondisi kering udara. Pengujian keteguhan rekat dilakukan dengan menempatkan contoh uji pada alat uji geser dan diberi tekanan sampai contoh uji rusak. Nilai keteguhan rekat, kerusakan kayu dan keteguhan rekat terkoreksi dihitung dengan rumus sebagai berikut [5]:

$$
\begin{array}{lll}
\mathrm{KR}\left(\mathrm{kg} / \mathrm{cm}^{2}\right) & = & \mathrm{P} / \mathrm{A} \\
\mathrm{KK}(\%) & = & \mathrm{K} / \mathrm{A} \times 100
\end{array}
$$

Keterangan :

$\begin{array}{ll}\mathrm{P} & =\text { Beban maksimum }(\mathrm{kg}) \\ \mathrm{A} & =\text { Luas bidang geser }\left(\mathrm{cm}^{2}\right) \\ \mathrm{K} & =\text { Luas kerusakan pada } \\ & \text { bidang geser }\left(\mathrm{cm}^{2}\right) \\ \mathrm{KR} & =\text { Keteguhan Rekat } \\ & \left(\mathrm{kg} / \mathrm{cm}^{2}\right) \\ \mathrm{KK} & =\text { Kerusakan Kayu }(\%)\end{array}$

Contoh perhitungan keteguhan rekat (KR); Kode specimen S2-85

$\mathrm{P} \quad=192,5 \mathrm{~kg}$ (Beban maksimum)

$\mathrm{A} \quad=10 \mathrm{~cm}^{2}$ (Luas bidang geser)

$\mathrm{KR} \quad=\mathrm{P} / \mathrm{A} \ldots . .($ hal. 41$)$

$\mathrm{KR}=\frac{192,5 \mathrm{~kg}}{10 \mathrm{~cm} 2} \quad=\mathbf{1 9 , 2 5} \mathrm{kg} / \mathrm{cm}^{2}$

Contoh perhitungan prosentase kerusakan kayu (KK);

Kode specimen $\mathbf{S 4 - 8 5}$

Pada specimen S4-85 prosentase kerusakan kayu sangat besar, sehingga untuk memudahkan pengukuran dengan autocad, yang dihitung adalah area yang tidak rusak. Langkah-langkah dapat dilihat seperti gambar berikut ini :

Langkah pertama, masukkan gambar foto specimen ke dalam halaman kerja Autocad 2007.

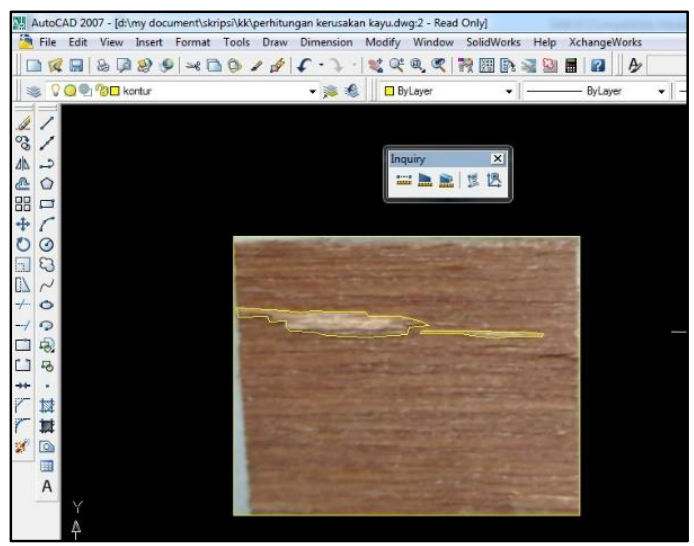

Gambar 10. Importing foto specimen ke dalam Autocad.

Langkah kedua, gunakan toolbar AREA yang berfungsi untuk menghitung luas area dan keliling geometri yang tidak beraturan.

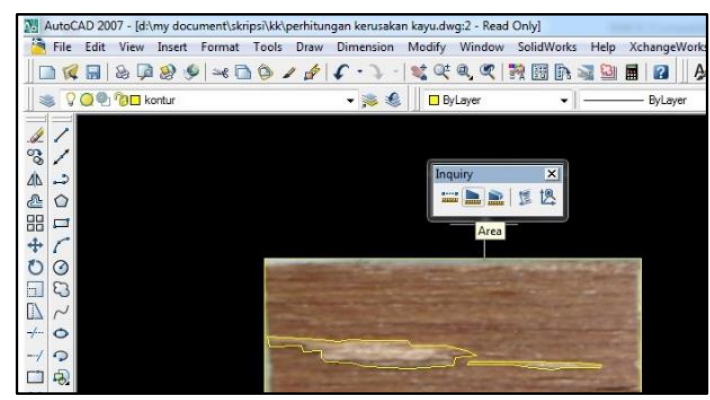

Gambar 11. Penggunaan toolbar AREA.

Langkah ketiga, klik toolbar AREA kemudian ikuti geometri yang akan 
dihitung dengan cara diklik sepresisi mungkin.

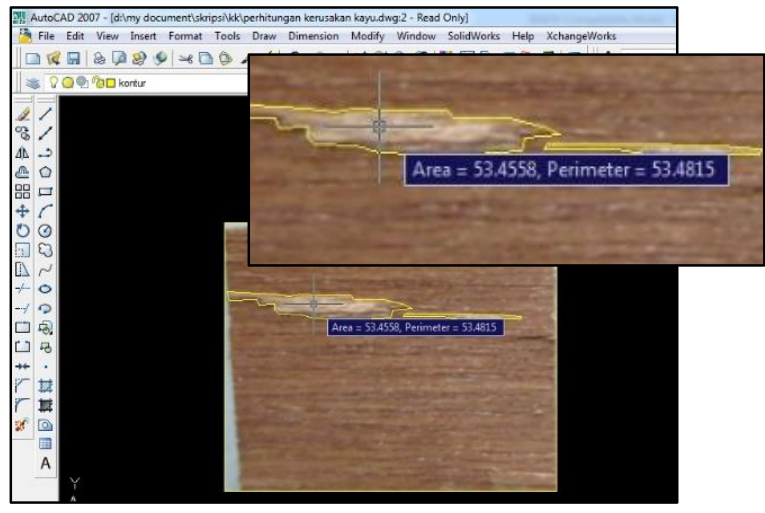

Gambar 12. Menghitung luas area 1

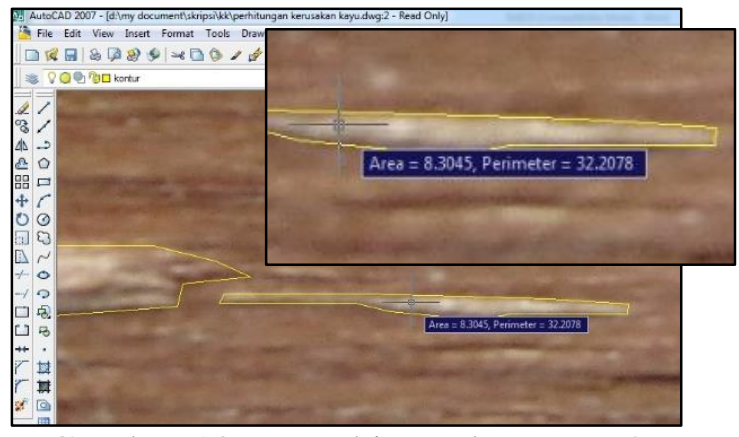

Gambar 13. Menghitung luas area 2

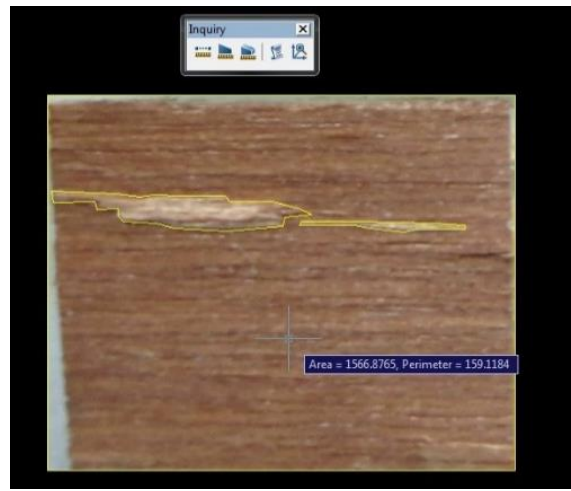

Gambar 14. Menghitung luas area seluruh permukaan kayu

\section{Contoh perhitungan prosentase luas kerusakan kayu :}

Area yang tidak rusak $=$ $\frac{\text { Luas area } 1+\text { Luas area } 2}{\text { Luas seluruh permukaan }} \times 100 \%$

Area yang tidak rusak $=$ $\frac{53,4558+8,3045}{15668765} \times 100 \%=$ $\frac{61,7603}{1566,8765} \times 100 \%=3,491 \%$

$\mathrm{KK}=100 \%$ - area yang tidak rusak

$\mathrm{KK}=100 \%-3,491 \%$

$\mathrm{KK}=96,509 \%$
Jadi prosentase kerusakan kayu (KK) untuk specimen $\mathbf{S 4 - 8 5}$ sebesar $\pm \mathbf{9 6 , 5 0 9 \%}$. Jika dihitung ulang menggunakan skala 1:1, perhitungan dengan metode ini memiliki tingkat ketelitian hingga $\mathbf{0 , 1} \mathrm{mm}^{2}$.

\section{HASIL DAN PEMBAHASAN}

Pengujian dilakukan dengan cara memvariasikan temperatur cetakan dan lama pengempaan menjadi sebanyak 9 variasi. Dari pengujian didapat data seperti pada tabel 2. Dari data pengujian yang berupa kekuatan rekat, dan prosentase kerusakan permukaan berdasarkan pengujian kuat rekat.

Tabel 2. Data awal hasil pengujian

\begin{tabular}{|c|c|c|c|c|c|}
\hline \multirow[b]{2}{*}{ No } & \multirow[b]{2}{*}{$\begin{array}{l}\text { Kode } \\
\text { spesim } \\
\text { en }\end{array}$} & \multirow[b]{2}{*}{$\begin{array}{c}\text { Beban } \\
\text { maks } \\
(\mathrm{kg})\end{array}$} & \multirow[b]{2}{*}{$\begin{array}{c}\text { Luas } \\
\text { bidang } \\
\text { Geser } \\
\left(\mathrm{cm}^{2}\right)\end{array}$} & \multicolumn{2}{|c|}{ Keteguhan rekat } \\
\hline & & & & $\begin{array}{c}(\mathrm{kg} / \mathrm{c} \\
\left.\mathrm{m}^{2}\right)\end{array}$ & $(\mathrm{Pa})$ \\
\hline 1 & $\mathrm{~S} 2-85$ & 192,5 & 10 & 19,25 & 1925000 \\
\hline 2 & S2-90 & 197,5 & 10 & 19,75 & 1975000 \\
\hline 3 & $\mathrm{~S} 2-95$ & 192,5 & 10 & 19,25 & 1925000 \\
\hline 4 & S3-85 & 212,5 & 10 & 21,25 & 2125000 \\
\hline 5 & S3-90 & 203,75 & 10 & $\begin{array}{c}20,37 \\
5\end{array}$ & 2037500 \\
\hline 6 & S3-95 & 212,5 & 10 & 21,25 & 2125000 \\
\hline 7 & S4-85 & 225,0 & 10 & 22,50 & 2250000 \\
\hline 8 & S4-90 & 232,5 & 10 & 23,25 & 2325000 \\
\hline 9 & S4-95 & 230,0 & 10 & 23,00 & 2300000 \\
\hline
\end{tabular}

Tabel 3. Proses pengempaan thermal dengan tekanan 1,5 Mpa

\begin{tabular}{|c|c|c|c|c|c|c|}
\hline \multirow{2}{*}{ No } & \multirow{2}{*}{$\begin{array}{c}\text { Kode } \\
\text { Specimen }\end{array}$} & $\begin{array}{c}\text { Lama } \\
\text { Pengempaan }\end{array}$ & $\begin{array}{c}\text { Temperatur } \\
\text { Cetakan }\end{array}$ & \multicolumn{2}{|c|}{ Keteguhan Rekat } & $\begin{array}{c}\text { Kerusakan } \\
\text { Kayu }\end{array}$ \\
\cline { 5 - 8 } & & $(\mathrm{Jam})$ & $\left({ }^{\circ} \mathrm{C}\right)$ & $(\mathrm{kg} / \mathrm{cm} 2)$ & $(\mathrm{Pa})$ & $(\%)$ \\
\hline 1 & $\mathrm{~S} 2-85$ & 2 & 85 & 19.25 & 1925000 & 100 \\
\hline 2 & $\mathrm{~S} 2-90$ & 2 & 90 & 19.75 & 1975000 & 73.39 \\
\hline 3 & $\mathrm{~S} 2-95$ & 2 & 95 & 19.25 & 1925000 & 72.56 \\
\hline 4 & $\mathrm{~S} 3-85$ & 3 & 85 & 21.25 & 2125000 & 70.85 \\
\hline 5 & $\mathrm{~S} 3-90$ & 3 & 90 & 20.375 & 2037500 & 100 \\
\hline 6 & $\mathrm{~S} 3-95$ & 3 & 95 & 21.25 & 2125000 & 71.31 \\
\hline 7 & $\mathrm{~S} 4-85$ & 4 & 85 & 22.5 & 2250000 & 93.23 \\
\hline 8 & $\mathrm{~S} 4-90$ & 4 & 90 & 23.25 & 2325000 & 96.46 \\
\hline 9 & $\mathrm{~S} 4-95$ & 4 & 95 & 23 & 2300000 & 95.31 \\
\hline
\end{tabular}

Keterangan :

S2-85 = Sampel dengan lama pengempaan 2 jam dan temperatur cetakan $85^{\circ} \mathrm{C}$.

S2-90 = Sampel dengan lama pengem 2 jam dan temperatur cetakan!

S2-95 = Sampel dengan lama pengemipaaı 2 jam dan temperatur cetakan $95^{\circ} \mathrm{C}$.

S3-85 = Sampel dengan lama pengempaan 3 jam dan temperatur cetakan $85^{\circ} \mathrm{C}$. 
S3-90 = Sampel dengan lama pengempaan

3 jam dan temperatur cetakan $90^{\circ} \mathrm{C}$.

S3-95 = Sampel dengan lama pengempaan

3 jam dan temperatur cetakan $95^{\circ} \mathrm{C}$.

S4-85 = Sampel dengan lama pengem 42

4 jam dan temperatur cetakan $8 \ldots$

S4-90 = Sampel dengan lama pengempaan

4 jam dan temperatur cetakan $90^{\circ} \mathrm{C}$.

S4-95 = Sampel dengan lama pengempaan

4 jam dan temperatur cetakan $95^{\circ} \mathrm{C}$.

\section{Analisa Data Pengaruh Temperatur Cetakan terhadap Keteguhan Rekat}

Dari hasil percobaan diperoleh data sebagai berikut :

Tabel 4. Pengaruh temperatur cetakan terhadap keteguhan rekat

\begin{tabular}{|c|c|c|c|c|}
\hline \multirow{2}{*}{ No } & \multirow{2}{*}{$\begin{array}{c}\text { Kode } \\
\text { Specimen }\end{array}$} & $\begin{array}{c}\text { Temperatur } \\
\text { Cetakan }\end{array}$ & \multicolumn{2}{|c|}{ Keteguhan Rekat } \\
\cline { 3 - 5 } & & $\left({ }^{\circ} \mathrm{C}\right)$ & $(\mathrm{kg} / \mathrm{cm} 2)$ & $(\mathrm{Pa})$ \\
\hline 1 & $\mathrm{~S} 2-85$ & 85 & 19.25 & 1925000 \\
\hline 2 & $\mathrm{~S} 2-90$ & 90 & 19.75 & 1975000 \\
\hline 3 & $\mathrm{~S} 2-95$ & 95 & 19.25 & 1925000 \\
\hline 4 & $\mathrm{~S} 3-85$ & 85 & 21.25 & 2125000 \\
\hline 5 & $\mathrm{~S} 3-90$ & 90 & 20.375 & 2037500 \\
\hline 6 & $\mathrm{~S} 3-95$ & 95 & 21.25 & 2125000 \\
\hline 7 & $\mathrm{~S} 4-85$ & 85 & 22.5 & 2250000 \\
\hline 8 & $\mathrm{~S} 4-90$ & 90 & 23.25 & 2325000 \\
\hline 9 & $\mathrm{~S} 4-95$ & 95 & 23 & 2300000 \\
\hline
\end{tabular}

Dari hasil percobaan, diperoleh nilai keteguhan rekat tertinggi pada sampel S4-90 dengan nilai keteguhan rekat sebesar $23,25 \mathrm{~kg} / \mathrm{cm}^{2}$ pada suhu $90^{\circ} \mathrm{C}$. Sedangkan nilai keteguhan rekat terendah terjadi pada sampel S2-85 dengan nilai keteguhan rekat sebesar $19,25 \mathrm{~kg} / \mathrm{cm}^{2}$ pada temperatur cetakan $85^{\circ} \mathrm{C}$ dan sampel $\mathrm{S} 2-95$ yaitu sebesar $19,25 \mathrm{~kg} / \mathrm{cm}^{2}$ pada suhu $95^{\circ} \mathrm{C}$.

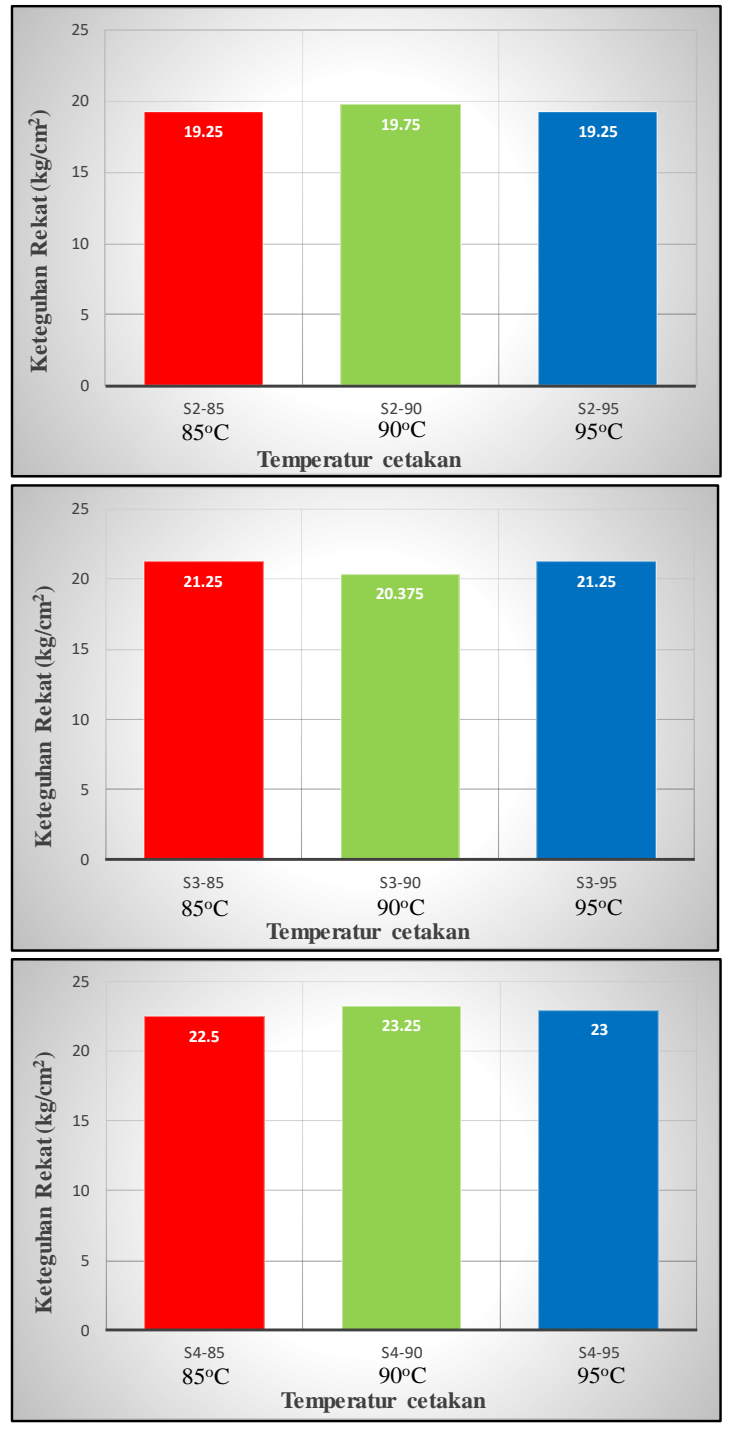

Gambar 15. Diagram Hubungan

Temperatur Cetakan terhadap Keteguhan Rekat

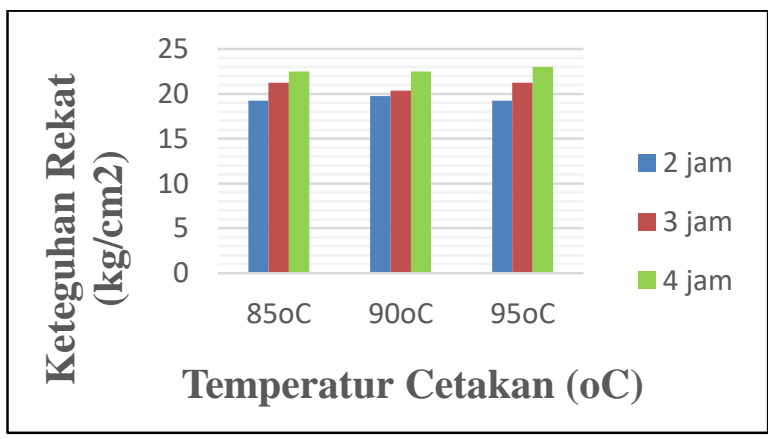

Gambar 16. Diagram gabungan Hubungan temperatur cetakan terhadap keteguhan rekat

Pada diagram yang pertama (dengan waktu pengempaan 2 jam), nilai keteguhan rekat pada temperatur cetakan 
$90^{\circ} \mathrm{C}$ lebih tinggi dibandingkan pada temperatur cetakan $85^{\circ} \mathrm{C}$, dan pada temperatur cetakan $95^{\circ} \mathrm{C}$ nilai keteguhan rekatnya sama dengan pengempaan pada suhu $85^{\circ} \mathrm{C}$.

Pada diagram yang kedua (dengan waktu pengempaan 3 jam), nilai keteguhan rekat pada temperatur cetakan $90^{\circ} \mathrm{C}$ justeru adalah yang paling rendah, kemudian meningkat lagi pada tempertur cetakan $95^{\circ} \mathrm{C}$.

Pada diagram ketiga (dengan waktu pengempaan 4 jam), peningkatan nilai keteguhan rekatnya kurang lebih sama denan diagram pertama (waktu pengempaan 2 jam) tetapi dengan nilai keteguhan rekat yang lebih besat.

Dalam aplikasi pembuatan drum shell, temperatur cetakan yang tinggi akan memperbaiki sifat-sifat dari kayu lapis menjadi lebih baik, diantaranya menurunkan kadar air, mengurangi kadar pentose yaitu sejenis protein yang menjadi nutrisi utama bagi jamur. Sehingga drum shell yang dibuat dengan perlakuan temperatur akan menjadi lebih awet.

\section{Analisa Data Pengaruh Lama Pengempaan terhadap Keteguhan Rekat}

5. berikut ini.

Dari hasil penelitian, didapat tabel

Tabel 5. Pengaruh Lama Pengempaan terhadap Keteguhan Rekat

\begin{tabular}{|c|c|c|c|c|}
\hline \multirow{2}{*}{ No } & \multirow{2}{*}{$\begin{array}{c}\text { Kode } \\
\text { Specimen }\end{array}$} & $\begin{array}{c}\text { Lama } \\
\text { Pengempaan }\end{array}$ & \multicolumn{2}{|c|}{ Keteguhan Rekat } \\
\cline { 3 - 5 } & & $(\mathrm{Jam})$ & $(\mathrm{kg} / \mathrm{cm} 2)$ & $(\mathrm{Pa})$ \\
\hline 1 & $\mathrm{~S} 2-85$ & 2 & 19.25 & 1925000 \\
\hline 2 & $\mathrm{~S} 2-90$ & 2 & 19.75 & 1975000 \\
\hline 3 & $\mathrm{~S} 2-95$ & 2 & 19.25 & 1925000 \\
\hline 4 & $\mathrm{~S} 3-85$ & 3 & 21.25 & 2125000 \\
\hline 5 & $\mathrm{~S} 3-90$ & 3 & 20.375 & 2037500 \\
\hline 6 & $\mathrm{~S} 3-95$ & 3 & 21.25 & 2125000 \\
\hline 7 & $\mathrm{~S} 4-85$ & 4 & 22.5 & 2250000 \\
\hline 8 & $\mathrm{~S} 4-90$ & 4 & 23.25 & 2325000 \\
\hline 9 & $\mathrm{~S} 4-95$ & 4 & 23 & 2300000 \\
\hline
\end{tabular}

Dari hasil percobaan, diperoleh nilai keteguhan rekat tertinggi pada sampel S4-90 dengan nilai keteguhan rekat sebesar
$23,25 \mathrm{~kg} / \mathrm{cm}^{2}$ dengan lama pengempaan 4 jam. Sedangkan nilai keteguhan rekat terendah terjadi pada sampel S2-85 dengan nilai keteguhan rekat sebesar $19,25 \mathrm{~kg} / \mathrm{cm}^{2}$ dengan lama pengempaan 2 jam dan sampel S2-95 yaitu sebesar $19,25 \mathrm{~kg} / \mathrm{cm}^{2}$ dengan lama pengempaan 2 jam. Dari tabel 5, dapat digambarkan ke dalam bentuk grafik pengaruh lama pengempaan terhadap keteguhan rekat berikut ini :
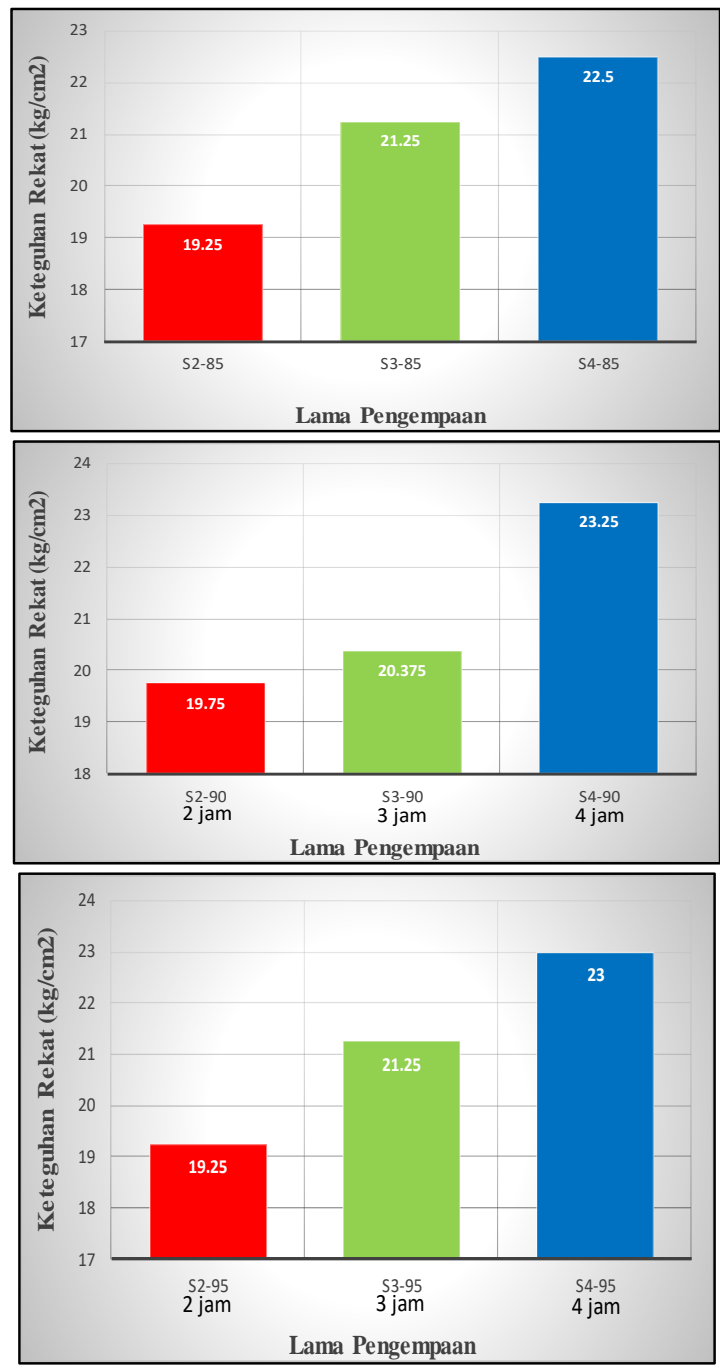

Gambar 17. Diagram Hubungan Lama pengempaan terhadap keteguhan rekat 


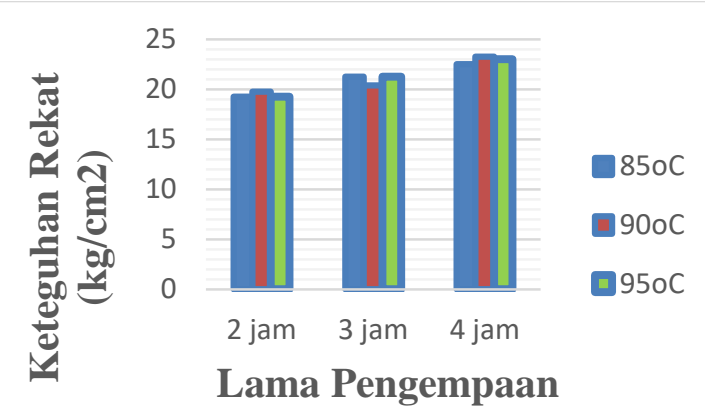

Gambar 18. Diagram gabungan Hubungan Lama pengempaan terhadap keteguhan rekat

Dalam penelitian ini, dari grafik dapat terlihat sebuah kecenderungan bahwa semakin lama waktu pengempaan akan semakin besar nilai keteguhan rekatnya pada proses perekatan. Hal ini diakibatkan karena dengan waktu kempa yang lebih lama, menyebabkan penyebaran perekat ke dalam alur pori kayu semakin banyak sehingga keteguhan rekatnya semakin baik.

Hal ini akan sangat baik apabila diterapkan pada pembuatan drum shell, karena semakin lama waktu pengempaan, selain menghasilkan keteguhan rekat yang semakin tinggi, juga akan meningkatkan keteguhan lengkung dari drum shell.

\section{Analisa Data Pengaruh Temperatur Cetakan terhadap Prosentase Kerusakan Kayu}

Dari data percobaan didapat tabel 6 di bawah ini:

Tabel 6. Pengaruh temperatur cetakan terhadap kerusakan kayu

\begin{tabular}{|c|c|c|c|}
\hline \multirow{2}{*}{ No } & \multirow{2}{*}{ Kode Specimen } & $\begin{array}{c}\text { Temperatur } \\
\text { Cetakan }\end{array}$ & Kerusakan Kayu \\
\cline { 3 - 4 } & $\left({ }^{\circ} \mathrm{C}\right)$ & $(\%)$ \\
\hline 1 & $\mathrm{~S} 2-85$ & 85 & 100 \\
\hline 2 & $\mathrm{~S} 2-90$ & 90 & 73.39 \\
\hline 3 & $\mathrm{~S} 2-95$ & 95 & 72.56 \\
\hline 4 & $\mathrm{~S} 3-85$ & 85 & 70.85 \\
\hline 5 & $\mathrm{~S} 3-90$ & 90 & 100 \\
\hline 6 & $\mathrm{~S} 3-95$ & 95 & 71.31 \\
\hline 7 & $\mathrm{~S} 4-85$ & 85 & 93.23 \\
\hline 8 & $\mathrm{~S} 4-90$ & 90 & 96.46 \\
\hline 9 & $\mathrm{~S} 4-95$ & 95 & 95.31 \\
\hline
\end{tabular}

Dari data hasil pengujian geser yang penulis lakukan, prosentase kerusakan kayu terbesar terjadi pada sampel dengan kode S2-85 dan S3-90 dengan kerusakan kayu sebesar $100 \%$, masing-masing terjadi pada temperatur cetakan $85^{\circ} \mathrm{C}$ dan $90^{\circ} \mathrm{C}$. Sedangkan nilai kerusakan kayu terendah terjadi pada sampel S3-85 dengan nilai kerusakan kayu $70,85 \%$ pada temperatur cetakan $85^{\circ} \mathrm{C}$.

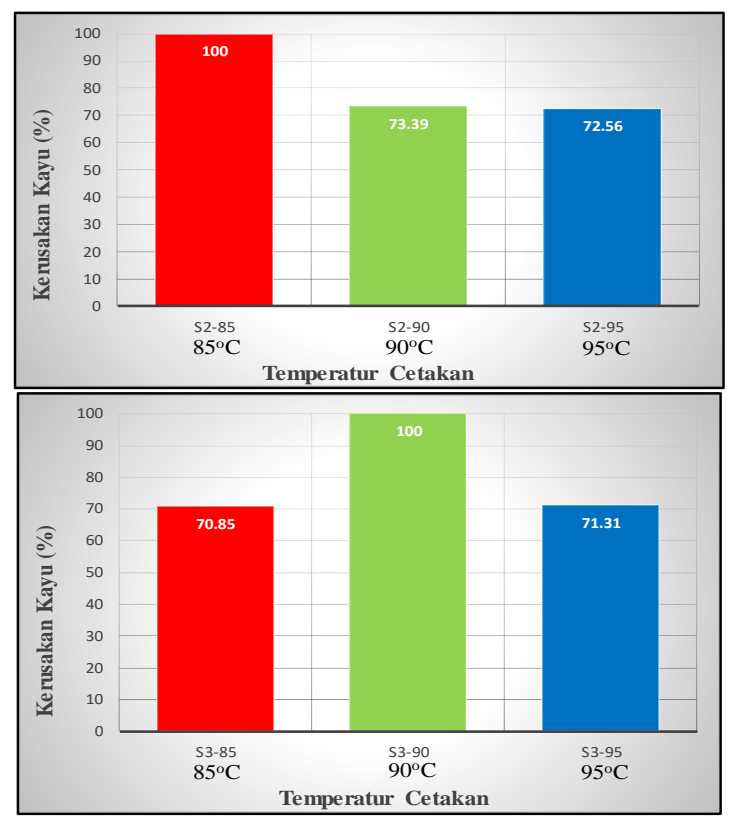

Gambar 19. Diagram hubungan temperatur cetakan terhadap kerusakan kayu

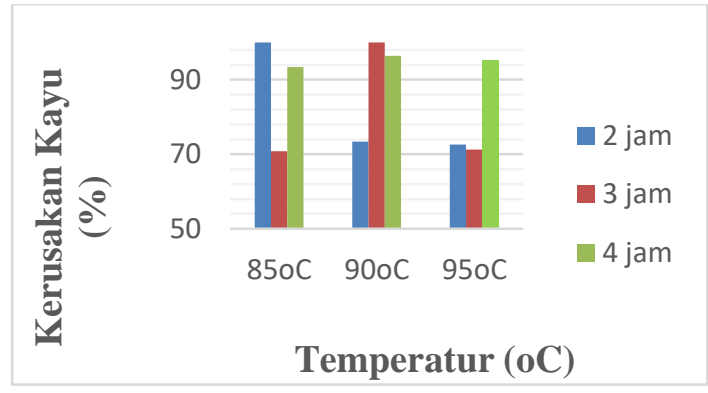

Gambar 20. Diagram gabungan hubungan temperatur cetakan terhadap kerusakan

kayu

Dalam penelitian ini, jika dilihat melalui diagram tidak dapat ditarik sebuah kesimpulan mengenai pengaruh yang signifikan dari temperatur cetakan terhadap kerusakan kayu. Dalam pembuatan drum shell, temperatur cetakan akan berakibat baik untuk meningkatkan keawetan kayu dan sifat-sifat fisik lainnya. 
Analisa Data Pengaruh Lama Pengempaan terhadap Kerusakan Kayu

Dari data dapat terlihat seperti tabel

7 dibawah ini:

Tabel 7. Pengaruh Lama Pengempaan terhadap Prosentase kerusakan Kayu

\begin{tabular}{|c|c|c|c|}
\hline \multirow{2}{*}{ No } & \multirow{2}{*}{ Kode Specimen } & Lama Pengempaan & Kerusakan Kayu \\
\cline { 3 - 4 } & & $($ Jam $)$ & $(\%)$ \\
\hline 1 & S2-85 & 2 & 100 \\
\hline 2 & S2-90 & 2 & 73.39 \\
\hline 3 & S2-95 & 2 & 72.56 \\
\hline 5 & S3-85 & 3 & 70.85 \\
\hline 6 & S3-90 & 3 & 100 \\
\hline 7 & S4-95 & 3 & 71.31 \\
\hline 8 & S4-90 & 4 & 93.23 \\
\hline 9 & S4-95 & 4 & 96.46 \\
\hline
\end{tabular}

Dari data dapat diketahui bahwa berdasarkan pengujian sampel yang memiliki kerusakan kayu terbesar adalah sampel dengan kode S2-85 sebesar 100\% dan S3-90 sebesar 100\%. Dan kerusakan kayu terkecil terjadi pada sampel S3-85 yaitu sebesar 70,85\%.

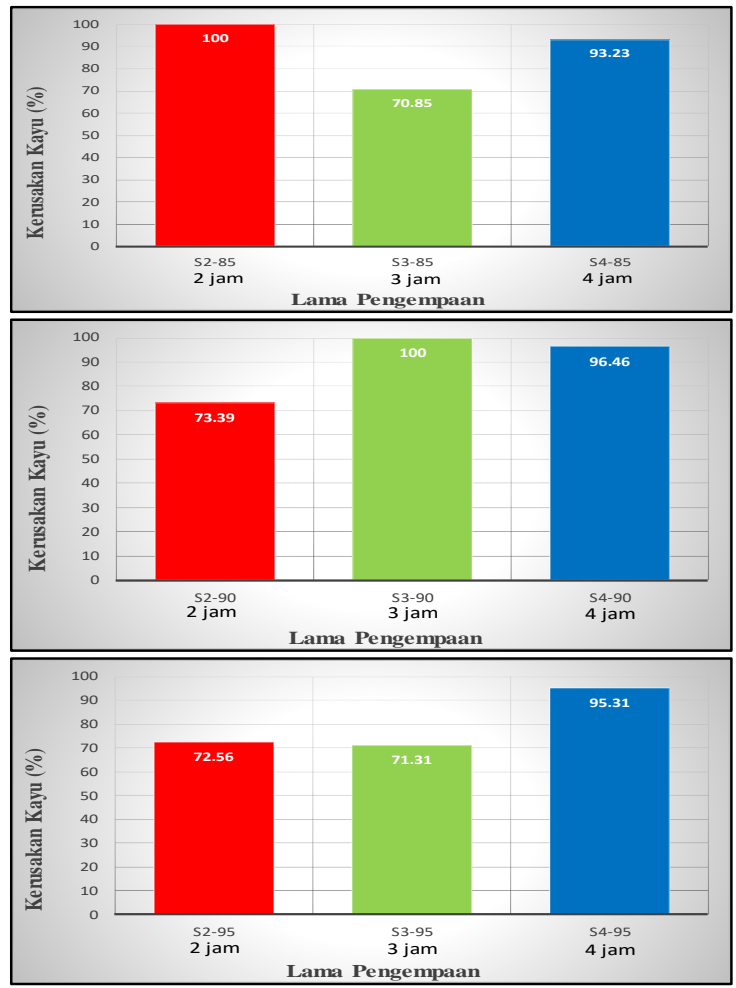

Gambar 21. Diagram Lama pengempaan terhadap prosentase kerusakan kayu

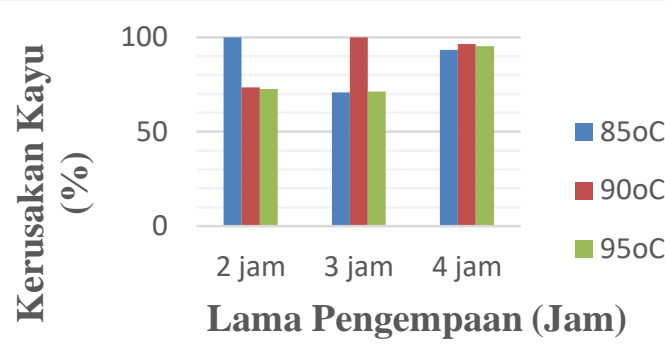

Gambar 22. Diagram Gabungan Lama pengempaan terhadap prosentase kerusakan kayu

Dari grafik gambar 22 dapat disimpulkan bahwa semakin lama waktu pengempaan, prosentase kerusakan kayu akan cenderung semakin besar luasannya. Semakin lama waktu pengempaan menyebabkan proses penyebaran perekat ke dalam pori-pori kayu semakin baik sehingga kekuatan rekatnya semakin besar pula. Dalam kasus umum yang terjadi adalah demikian. Tetapi dalam kasus tertentu seperti yang terjadi pada beberapa sampel tidaklah demikian. Penulis berpendapat hal tersebut dikarenakan karena hal-hal yang lain atau faktor dari luar. Menurut analisa penulis, hal ini terjadi karena perekat bawaan dari kayu lapis pabrikan berbeda kualitasnya dari perekat yang penulis gunakan untuk penelitian.

Apabila diaplikasikan dalam pembuatan drum shell, maka semakin lama waktu pengempaan akan semakin baik karena menyebabkan kadar air dalam kayu lapis akan berkurang, berat jenis meningkat, dan keteguhan lengkungnya semakin baik sehingga mendukung kualitas suara dan keawetan dari drum shell tersebut.

\section{KESIMPULAN}

1. Dalam penelitian ini, nilai keteguhan rekat paling tinggi terjadi pada temperatur cetakan $90^{\circ} \mathrm{C}$ yaitu sebesar $23,25 \mathrm{~kg} / \mathrm{cm}^{2}$. Dan nilai keteguhan rekat paling rendah terjadi pada temperatur cetakan $85^{\circ} \mathrm{C}$ dan $95^{\circ} \mathrm{C}$ yaitu sebesar $19,25 \mathrm{~kg} / \mathrm{cm}^{2}$. Jadi, dalam penelitian ini temperatur cetakan yang 
paling baik adalah pada termperatur $90^{\circ} \mathrm{C}$.

2. Dalam penelitian ini, pengaruh lama pengempaan terhadap keteguhan rekat yaitu semakin lama waktu pengempaan akan menyebabkan keteguhan rekat semakin tinggi. Dalam penelitian ini, nilai keteguhan rekat paling tinggi terjadi pada waktu pengempaan 4 jam yaitu sebesar $23,25 \mathrm{~kg} / \mathrm{cm}^{2}$. Dan nilai keteguhan rekat paling rendah terjadi pada waktu pengempaan 2 jam yaitu sebesar 19,25 $\mathrm{kg} / \mathrm{cm}^{2}$. Jadi lama pengempaan terbaik dalam penelitian ini adalah 4 jam.

3. Dalam penelitian ini, nilai kerusakan kayu tertinggi sebesar $100 \%$ pada temperatur cetakan $85^{\circ} \mathrm{C}$ dan $90^{\circ} \mathrm{C}$. Dan prosentase kerusakan kayu terendah adalah $70,85 \%$ pada temperatur cetakan $85^{\circ} \mathrm{C}$.

4. Dalam penelitian ini nilai kerusakan kayu tertinggi sebesar $100 \%$ pada lama pengempaan 2 jam dan 3 jam. Dan prosentase kerusakan kayu terendah adalah $70,85 \%$ pada lama pengempaan 3 jam.

\section{REFERENSI}

[1] Departemen Kehutanan. 2008. Sifatsifat Kayu dan Penggunaannya, www. Dephut.go.id.

[2] Azzarto, Fran. 2015. What You Need to Know About Drum Shells. www.moderndrummer.com

[3] Lucky. 2013. Ketebalan Kayu pada Shell Drum dan Sound. Citra Intirama. www.Citraintirama.com

[4] Kindersley, Dorling. 2008. Jendela IPTEK. Balai Pustaka: Jakarta.

[5] Prayitno. 2008. Kualitas Perekatan Dua Jenis kayu Hutan Rakyat dengan Variasi Perlakuan Panas. Fakultas Kehutanan Universitas Gajah Mada.

[6] Iswanto, Apri Heri. 2009. Perlakuan Panas pada Kayu. Fakultas
Pertanian Unversitas Sumatera Utara.

[7] Sudiryanto, Gun. 2015. Pengaruh Suhu dan Waktu Pengempaan Terhadap Sifat Fisik dan Mekanik Papan Partikel Kayu Sengon. Universitas Islam Nahdlatul Ulama: Jepara. 